\title{
PENGARUH IMPLEMENTASI SISTEM AKUNTANSI, PENGELOLAAN KEUANGAN DAERAH DAN PENGAWASAN INTERNAL TERHADAP KINERJA PEMERINTAH KOTA KOTAMOBAGU
}

\author{
Diana Nova Lintong ${ }^{1}$, David Paul Elia Saerang ${ }^{2}$, Ventje Ilat ${ }^{3}$ \\ 1,2,3 Jurusan Akuntansi, Fakultas Ekonomi dan Bisnis, Universitas Sam Ratulangi, Jl. Kampus Bahu, Manado, \\ 95115, Indonesia \\ E-mail : nova.lintong@gmail.com
}

\begin{abstract}
Governance implementation of good government in a country is an inevitable requirement. The Government shall apply the rules of good in running the Government, including the rules in the field of financial management. governments need to have an accounting system that not only serves as a means of controlling financial transactions, but the financial accounting system should support the achievement of the performance. Because the assessment Good governance can be seen from the achievement of the Government's own performance, measuring the achievement of performance is critical to assess the accountability of organizations and managers to produce better public services. (Sukmana and Anggasari, 2009). The purpose of this study was to determine the effect of implementation Accounting System, Financial Management and Internal Controls have a significant impact on the Kotamobagu City Local Government Performancent. The object of this research is Kotamobagu City Government. Instruments in this study was a questionnaire with Likert scale 1-5 and processed using SPSS 19. The analytical method used is multiple linear regression analysis. The conclusion of this study are implementation Accounting System, Regional Financial Management and internal controls jointly significant effect on the performance of Local Government with a contribution of $50.5 \%$, whereas only partially Accounting System and Regional Financial Management that significantly influence the Local Government Performance, Suggestions from this study is that the government that Kotamobagu further enhance the system of reward and punishment and the Kotamobagu Government Performance should also be maintained or improved further in terms of internal oversight.
\end{abstract}

Keywords: Systems, accounting, management, monitoring, performance

\section{PENDAHULUAN}

Seiring dengan pemberlakuan otonomi daerah sejak tanggal 1 januari 2001 melalui Undang-Undang No.2 tahun 1999 yang telah direvisi dengan Undang-Undang N0. 32 tahun 2004 tentang Pemerintah daerah,reformasi aspek keuangan negara baik di pemerintah pusat dan pemerintah daerahpun berjalan dengan dikeluarkannya Undang-Undang No. 25 Tahun 1999 yang direvisi dengan Undang-Undang No. 33 Tahun 2004 tentang Perimbangan Keuangan Pusat dan Pemerintah Daerah, selanjutnya reformasi keuangan negara ditetapkan dengan undang-undang No. 17 tahun 2003 tentang Keuangan Negara. Untuk mewujudkan kinerja pemerintah yang memuaskan dalam hal ini tata kelola pemerintahan yang baik (good governance),maka pemerintah terus melakukan berbagai upaya perbaikan guna meningkatkan transparansi dan akuntabilitas pengelolaan keuangan negara/daerah salah satunya dengan penyempurnaan sistem akuntansi dan administrasi secara menyeluruh dengan menerbitkan seperangkat peraturan perundangan terkait pengelolaan keuangan negara/daerah. Permendagri 59 Tahun 2007 yang merupakan perubahan atas Peraturan Menteri Dalam Negeri Nomor 13 Tahun 2006 tentang Pedoman Pengelolaan Keuangan Daerah, menyatakan 
bahwa keuangan daerah adalah sebagai berikut: "Pengelolaan keuangan daerah adalah keseluruhan kegiatan yang meliputi perencanaan, pelaksanaan, penatausahaan, pelaporan, pertanggungjawaban dan pengawasan keuangan daerah."

Pasal 3 Peraturan Pemerintah Nomor 58 Tahun 2005 Pengelolaan Keuangan daerah meliputi azas umum pengelolaan keuangan daerah, pejabat-pejabat yang mengelola keuangan daerah, struktur APBD, Penyusunan RKPD, KUA, PPAS, dan RKA-SKPD, penyusunan dan penetapan APBD, pelaksanaan dan perubahan APBD, penatausahaan keuangan daerah, pertanggungjawaban pelaksanaan APBD, pengendalian defisit dan penggunaan surplus APBD, pengelolaan kas umum daerah, pengelolaan piutang daerah, pengelolaan investasi daerah, pengelolaan barang milik daerah, pengelolaan dana cadangan, pengelolaan utang daerah, pembinaan dan pengawasan pengelolaan keuangan daerah, penyelesaian kerugian daerah,pengelolaan keuangan badan layanan umum daerah, pengaturan pengelolaan keuangan daerah.

Sedangkan menurut Peraturan Pemerintah No. 58 tahun 2005 tentang pengelolaan keuangan daerah pasal 1 ayat 5 yaitu: "Keuangan daerah adalah segala hak dan kewajiban daerah dalam rangka penyelenggaraan pemerintah daerah yang dapat dinilai dengan uang termasuk didalamnya segala bentuk kekayaan yang berhubungan dengan hak dan kewajiban daerah tersebut, dalam kerangka anggaran pendapatan dan belanja daerah". Permendagri 59 Tahun 2007 yang merupakan perubahan atas Peraturan Menteri Dalam Negeri Nomor 13 Tahun 2006 tentang Pedoman Pengelolaan Keuangan Daerah, menyatakan bahwa keuangan daerah adalah sebagai berikut: "Pengelolaan keuangan daerah adalah keseluruhan kegiatan yang meliputi perencanaan, pelaksanaan, penatausahaan, pelaporan, pertanggungjawaban dan pengawasan keuangan daerah."

Secara umum pengelolaan keuangan daerah sering menghadapi masalah ketika perencanaan dan penganggaran tidak dilakukan dan tidak berjalan dengan baik. Banyak permasalahan yang terjadi berkaitan dengan pengelolaan keuangan pemerintah daerah diantaranya, pendekatan partisipatif dalam perencanaan melalui mekanisme musrenbang masih menjadi retorika,perencanaan pembangunan masih didominasi oleh kebijakan kepala daerah. Adanya proses perencanaan kegiatan terpisah dari penganggaran yang disebabkan oleh kualitas tenaga perencana di SKPD yang terbatas baik secara kuantitas maupun kualitasnya, perencanaan hanya dibuat oleh pengguna anggaran dan bendahara, kelemahan lain adalah indikator capaian seringkali tidak jelas dan tidak terukur serta pendalaman analisis yang kurang dan seharusnya mengarah pada "how to achieve" suatu target bukannya memenuhi “order" kepentingan. Dalam proses perencanaan perlu didorong kontribusi setiap SKPD untuk mengatasi kemiskinan sesuai tupoksi dan pengkoordinasian kegiatan antar SKPD dalam proses perencanaan yang berimplikasi pada sinergisitas sehingga jauh dari kegiatan egosektoral dan menyebabkan ketimpangan kegiatan antar SKPD.

Keberhasilan sebuah organisasi tidak dapat diukur semata-mata dari pespektif keuangan. Surplus atau defisit dalam laporan keuangan tidak dapat menjadi tolak ukur keberhasilan. Karena sifat dasarnya yang tidak mencari profit, keberhasilan sebuah organisasi sektor publik juga harus diukur dari kinerjanya (Mardiasmo, 2004). Organisasi pemerintah senantiasa menghadapi permasalahan yang kompleks dan persoalan yang paling umum adalah adanya kesalahan administrasi serta tindak pidana korupsi. Keberadaan lembagalembaga pengawas semakin diperlukan, namun apakah dengan jumlah lembaga-lembaga pengawasan yang cukup banyak dan pelaksanaan pengawasan yang belapis-lapis dapat memperoleh hasil yang efektif, oleh karena inilah semakin banyaknya waktu yang harus disediakan hanya untuk melayani aparat pengawasan. Hal-hal seperti ini yang harus dipikirkan dan dicarikan solusinya untuk kepentingan yang lebih luas, apakah dengan melakukan penyederhanaan terhadap lembaga-lembaga pengawasan yang ada ataukah 
membuat suatu aturan yang jelas dan tegas dengan tetap berpegang teguh pada upaya-upaya peningkatan kinerja pemerintah (Ihyaul, 2004:85).

Pengukuran kinerja merupakan suatu alat manajemen yang digunakan untuk meningkatkan kualitas pengambilan keputusan dan akuntabilitas dalam rangka menilai keberhasilan/kegagalan pelaksanaan kegiatan/program, kebijakan dan kesesuain dengan sasaran dan tujuan yang telah ditetapkan dalam rangka mewujudkan misi dan visi instansi pemerintah (LAN, 2000: 47). Penelitian ini menggunakan variabel sistem akuntansi, pengelolaan keuangan dan pengawasan intern sebagai variabel bebas yang diduga berpengaruh terhadap kinerja pemerintah sebagai variabel terikat. Alasan dipilihnya sistem akuntansi sebagai variabel bebas, berdasarkan PP No.24 Tahun 2005 tentang Standar Akuntansi Pemerintahan menyatakan : "Sistem akuntansi pemerintahan adalah serangkaian prosedur manual maupun yang terkomputerisasi mulai dari pengumpulan data, pencatatan, pengikhtisaran dan pelaporan posisi keuangan dan operasi pemerintah." PP Nomor 71 tahun 2010 dalam penyusunan pelaporan keuangan daerah, diperlukan sistem yang mengatur proses pengklasifikasian, pengukuran, dan pengungkapan seluruh transaksi keuangan yang disebut sistem akuntansi.

Alasan dipilihnya pengawasan intern sebagai variabel bebas karena pihak yang paling bertanggungjawab atas kesesuaian pelaksanaan kegiatan dengan tujuan dan rencana adalah pihak atasan, maka pengawasan sesungguhnya mencakup baik aspek pengendalian maupun aspek pemeriksaan yang dilakukan oleh pihak atasan terhadap bawahannya. Baswir (1999) mengungkapkan bahwa tujuan pengawasan pada dasarnya adalah untuk mengamati apa yang sungguh-sungguh terjadi serta membandingkannya dengan apa yang seharusnva Sedangkan pengawasan atas keuangan negara secara garis besar dibedakan menjadi 2 macam yaitu pengawasan internal dan pengawasan eksternal.

Alasan pemilihan objek penelitian di DPPKAD Kotamadya Kotamobagu selaku bendahara daerah, karena penulis tertarik dengan hasil audit BPK dengan opini WTP (Wajar Tanpa Pengecualian) yang diberikan pada pemerintah daerah kotamadya kotamobagu. Apakah opini wajar tanpa pengecualian mencerminkan peningkatan dan perbaikan kinerja yang tercermin dalam peningkatan kesejahteraan masyarakat, ataukah hasil audit BPK hanya menggambarkan tingkat kesesuaian antara sistem dan prosedur yang telah ditetapkan sesuai dengan perundangan yang ada ,tanpa menelaah lebih lanjut apakah pelaksanaan suatu program atau kegiatan telah benar-benar mencerminkan kebutuhan masyarakat dan telah dilaksanakan secara benar,dan tepat.

\section{TINJAUAN PUSTAKA}

\subsection{Sistem Akuntansi Pemerintahan daerah}

Kepmendagri No. 13 Tahun 2006, mengemukakan : "Sistem Akuntansi Pemerintahan daerah sebagaimana yang dimaksud pada ayat (1) meliputi serangkaian prosedur mulai dari proses pengumpulan data, pencatatan, pengikhtisaran,sampai dengan pelaporan keuangan dalam rangka pertanggungjawaban pelaksanaan APBD yang dapat dilaksanakan secara manual atau menggunakan aplikasi Komputer".

"Sistem akuntansi keuangan daerah (SAKD) adalah suatu sistem akuntansi yang melalui ptoses pencatatan, penggolongan, penafsiran, peringkasan, transaksi atas kejadian keuangan serta pelaporan keuangannya dalam rangka pelaksanaan APBD, dilaksanakan sesuai dengan prinsip-prinsip akuntansi" (Pasal 70: ayat 1). Dengan pengertian diatas dapat ditarik kesimpulan bahwa sistem akuntansi keuangan daerah merupakan serangkaian prosedur yang saling berhubungan yang disusun sesuai suatu skema yang menyeluruh yang ditinjau untuk menghasilkan informasi dalam bentuk laporan keuangan yang akan digunakan oleh pihak intern dan pihak ekstern pemerintah daerah untuk mengambil keputusan ekonomi. Dasar hukum penyelenggaraan sistem akuntansi keuangan daerah : 
1. Undang-undang Nomor 17 Tahun 2003 tentang Keuangan Negara.

2. Undang-undang Nomor 1 Tahun 2004 tentang Perbendaharaan Negara.

3. Undang-undang Nomor 15 Tahun 2004 tentang pelaksanaan Pengelolaan dan Tanggung Jawab Keuangan Negara.

4. Undang-undang Nomor 32 Tahun 2004 tentang Pemerintah Daerah.

5. Undang-undangNomor 58 Tahun 2005 tentang Pengelolaan keuangan Daerah.

6. Undang-undang Nomor 13 Tahun 2006 tentang Pedoman Pengelolaan Keuangan Daerah sebagaimana telah diubah dengan Permendagri Nomor 59 Tahun 2007 (Perubahan I) dan Permendagri Nomor 21 Tahun 2011 (Perubahan II)

7. Peraturan Pemerintah Nomor 71 Tahun 2010 Tentang Standar Akuntansi Pemerintahan.

\subsection{Pengelolaan keuangan}

Menurut Arinta Kustandi (1995:151) mengenai pengelolaan keuangan daerah : Pengelolaan keuangan Negara pada hakekatnya adalah pengelolaan APBN dan jika kita berbicara pengelolaan keuangan daerah menurut Halim (2004:2) pengelolaan keuangan daerah tidak terlepas dari pembahasan APBD. Pasal 3 Peraturan Pmerintah Nomor 58 Tahun 2005 Pengelolaan Keuangan daerah meliputi azas umum pengelolaan keuangan daerah, pejabat-pejabat yang mengelola keuangan daerah, struktur APBD, Penyusunan RKPD, KUA, PPAS, dan RKA-SKPD, penyusunan dan penetapan APBD, pelaksanaan dan perubahan APBD,penatausahaan keuangan daerah, pertanggungjawaban pelaksanaan APBD, pengendalian defisit dan penggunaan surplus APBD, pengelolaan kas umum daerah, pengelolaan piutang daerah, pengelolaan investasi daerah, pengelolaan barang milik daerah, pengelolaan dana cadangan, pengelolaan utang daerah, pembinaan dan pengawasan pengelolaan keuangan daerah, penyelesaian kerugian daerah,pengelolaan keuangan badan layanan umum daerah, pengaturan pengelolaan keuangan daerah.

Devas dalam Halim dan Rohman (2009) mengemukakan, bahwa tujuan utama dari pengelolaan keuangan daerah adalah pertanggungjawaban, mampu memenuhi kewajiban, kejujuran, hasil guna, dan daya guna kegiatan daerah serta pengendalian petugas keuangan pemerintah daerah. Halim dan Rohman (2008) menyatakan bahwa pengelolaan keuangan yang berorientasi pada kinerja menunjukan adanya akuntabilitas kineja yang terdapat keterkaitan antara sasaran strategis yang ingin dicapai dan jumlah dana yang dialokasikan. Maka dapat diasumsikan bahwa pengelolaan keuangan daerah yang baik akan berperpengaruh terhadap kinerja keuangan pemerintah daerah.

\subsection{Pengawasan internal}

Pengertian pengawasan internal menurut Mulyadi (2001:163) adalah: "Pengawasan intern meliputi struktur organisasi, metode dan ukuran-ukuran yang dikoordinasikan untuk menjaga kekayaan organisasi, mengecek ketelitian dan keandalan data akuntansi, mendorong efisensi dan mendorong dipatuhinya kebijakan manajemen". SAS (Statement on Auditing Standard) mendefinisikan pengawasan intern sebagai berikut :

a. Pengawasan administrasi, meliputi struktur organisasi, prosedur dan catatan yang berhubungan dengan proses pengambilan keputusan untuk melaksanakan transakasi yang diotorisasi oleh manajemen.

b. Pengawasan akuntansi, meliputi struktur organisasi serta prosedur dan catatan yang berhubungan dengan usaha untuk menjaga keamanan aktiva dan dipercayainya catatan keuangan perusahaan.

c. Kinerja pemerintah daerah merupakan gambaran mengenai tingkat pencapaian pelaksanaan suatu kegiatan/program/kebijakan dalam mewujudkan sasaran, tujuan, misi dan visi organisasi yang tertuang dalam perumusan skema strategis (strategic planning) suatu organisasi. 


\subsection{Kinerja}

Secara umum dapat juga dikatakan bahwa kinerja merupakan prestasi yang dapat dicapai organisasi dalam dalam periode tertentu (Rohman, 2009). Kinerja pemerintah daerah berarti bagaimana atau sejauh mana pemerintah daerah menyelenggarakan urusan - urusan tersebut. Informasi yang digunakan untuk pengukuran kinerja dibagi dua yaitu informasi financial dan informasi nonfinancial (Sukmana dan Anggasari, 2009). Kinerja adalah kemampuan yang ditunjukan dengan hasil kerja. Atmosudirjo dan Harijanto (2009) Kinerja dapat dijelaskan sebagai suatu kajian suatu organisasi dalam pencapaian tujuan. Pencapaian dapat dipakai untuk mengukur kegiatan-kegiatan organisasi dalam pencapaian tujuan dan juga sebagai bahan utuk perbaikan dimasa yang akan datang.

\subsection{Penelitian terdahulu}

Tabel 1. Daftar Penelitian Terdahulu

\begin{tabular}{|c|c|c|c|}
\hline No & $\begin{array}{c}\text { Nama } \\
\text { Peneliti/ } \\
\text { Tahun }\end{array}$ & Judul & Hasil Penelitian \\
\hline 1. & $\begin{array}{l}\text { Rohman } \\
\text { (2009) }\end{array}$ & $\begin{array}{l}\text { Pengaruh Implementasi Sistem } \\
\text { Akuntansi, Pengelolaan } \\
\text { Keuangan Daerah terhadap } \\
\text { Fungsi Pengawasan dan } \\
\text { Kinerja Pemerintah Daerah } \\
\text { (Survei pada Pemda di Jawa } \\
\text { Tengah) }\end{array}$ & $\begin{array}{l}\text { Implementasi sistem akuntansi } \\
\text { pemerintahan } \\
\text { implementasi dan } \\
\text { keuangan daerah bengelolaan } \\
\text { terhadap fungsi pengawasan } \\
\text { intern. Dan fungsi pengawasan } \\
\text { intern berpengaruh terhadap } \\
\text { kinerja Pemda. }\end{array}$ \\
\hline 2. & $\begin{array}{l}\text { Fawzi } \\
(2012)\end{array}$ & $\begin{array}{l}\text { Pengaruh Pengawasan Intern } \\
\text { Dan Sistem Informasi } \\
\text { Akuntansi Terhadap Kinerja } \\
\text { Pemerintahan (Survei Pada } \\
\text { Organisasi Perangkat Daerah } \\
\text { (Opd) Pemerintah Kota } \\
\text { Tasikmalaya) }\end{array}$ & $\begin{array}{l}\text { (1) Pengawasan intern, sistem } \\
\text { informasi akuntansi dan kinerja } \\
\text { Pemerintahan pada Dinas yang } \\
\text { berada di Kota Tasikmalaya } \\
\text { termasuk kategori sangat baik; } \\
\text { (2) Hubungan antara } \\
\text { pengawasan intern dan sistem } \\
\text { informasi akuntansi pada Dinas } \\
\text { yang berada di Kota } \\
\text { Tasikmalaya tergolong kuat } \\
\text { dengan koefisien korelasi } \\
\text { sebesar } 0,709 \text { (t-hitung=3,014, } \\
\text { sig = 0,015); (3)Terdapat } \\
\text { pengaruh signifikan secara } \\
\text { parsial maupunsimultan } \\
\text { pengawasan intern dan sistem } \\
\text { informasi akuntansi terhadap } \\
\text { kinerja pemerintahan yang } \\
\text { berada di Kota Tasikmalaya (F- } \\
\text { hitung = 26,350, sig = 0,000). }\end{array}$ \\
\hline
\end{tabular}




\section{KERANGKA KONSEPTUAL}

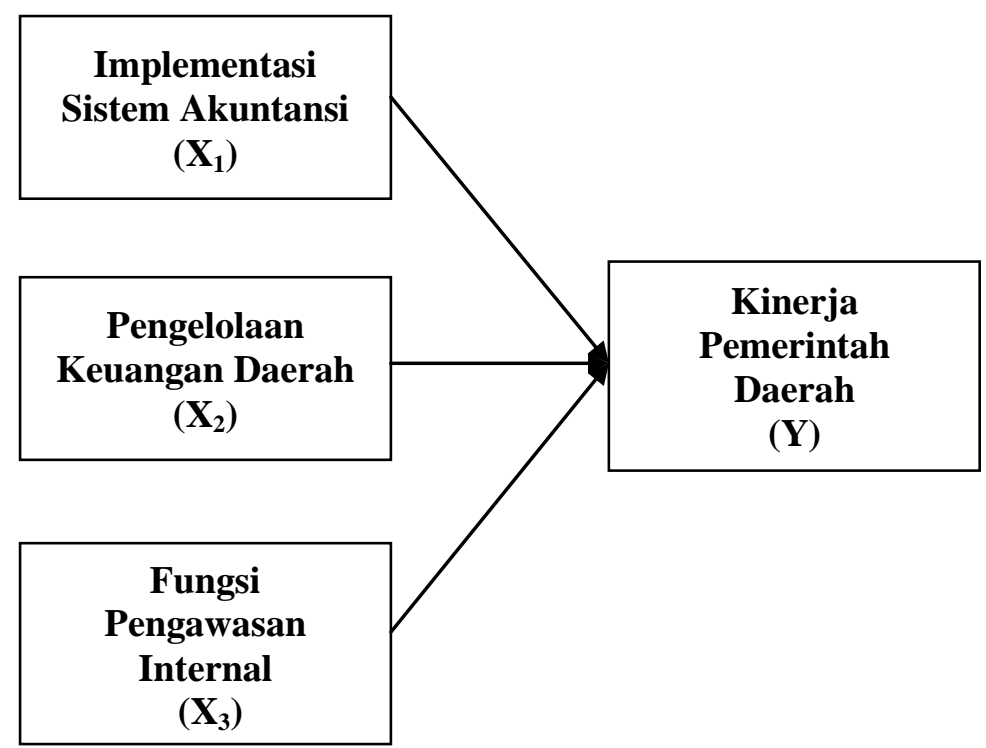

1. Implementasi Sistem Akuntansi merupakan penerapan dari pedoman pokok dalam penyusunan dan penyajian laporan keuangan pemerintah.

2. Pengelolaan Keuangan Daerah merupakan suatu aktivitas yang mencakup tahap perencanaan, tahap penyusunan dan penetapan APBD, tahap pelaksanaan APBD termasuk didalamnya bagaimana penatausahaannya, tahap pertanggungjawaban, dan pengawasan.

3. Pengawasan Internal merupakan suatu fungsi penilaian yang independen dalam suatu organisasi untuk menguji dan mengevaluasi kegiatan organisasi yang dilakukan.

4. Kinerja pemerintah daerah merupakan gambaran mengenai tingkat pencapaian pelaksanaan suatu kegiatan/program/kebijaksanaan dalam mewujudkan sasaran, tujuan, misi dan visi organisasi yang tertuang dalam perumusan skema strategis suatu organisasi. Secara umum dapat dikatakan juga bahwa kinerja merupakan prestasi yang dapat dicapai organisasi dalam periode tertentu.

Implementasi sistem akuntansi pemerintahan memberikan kemanfaatan dan kemudahan bagi pemda dalam mewujudkan transparansi dan akuntabilitas pengelolaan keuangan daerah sehingga pelaksanaan program kegiatan terekam dengan baik dan memiliki ukuran-ukuran yang jelas dalam penyajian laporan keuangan. Hal ini sesuai dengan penelitian yang dilakukan Rohman (2009) yang menyatakan Implementasi sistem akuntansi pemerintahan dan implementasi pengelolaan keuangan daerah berpengaruh terhadap fungsi pengawasan intern. Dan fungsi pengawasan intern berpengaruh terhadap kinerja Pemda.

H1: Ada pengaruh signifikan Implementasi Sistem Akuntansi terhadap Kinerja Pemerintah Daerah di Pemerintahan Kota Kotamobagu.

Pengelolaan keuangan daerah telah mendorong peningkatan kinerja Pemerintah daerah, sebab dengan proses pengelolaan keuangan menekankan pada hubungan antara dana yang dianggarkan dengan hasil-hasil yang ingin dicapai, (Rohman,2009).

H2: Ada pengaruh signifikan Pengelolaan Keuangan Daerah terhadap Kinerja Pemerintah Daerah di Pemerintah kota Kotamobagu.

Fungsi pemeriksaan intern membantu para pegawai pemda dalam melaksanakan tanggungjawabnya dengan melakukan analisis, dan penilaian atas operasional pemda serta mengajukan saran-saran perbaikan atas penyimpangan yang ditemukan. Fungsi ini bertanggungjawab memonitor kinerja pengendalian pemda yang berorientasi pada 
pelaksanaan pertanggungjawaban keuangan masa yang lalu, dan penilaian atas semua program dan kegiatan operasional Pemda. Dengan demikian, fungsi pemeriksaan intern membantu Pemda dalam mencapai kinerjanya yang lebih baik. (Rohman,2009).

H3: Ada pengaruh signifikan Pengawasan Internal terhadap Kinerja Pemerintah Daerah di Pemerintah Kota Kotamobagu.

\section{METODE PENELITIAN}

Unit analisis adalah Pemkot Kotamobagu dalam hal ini Dinas Pendapatan, Pengelolaan Keuangan dan Aset Daerah kota Kotamobagu. Dalam penelitian ini tidak dilakukan pengambilan sampel artinya semua anggota populasi dijadikan sampel.Responden adalah orang-orang yang melaksanakan fungsi perencanaan, penganggaran, keuangan, verifikasi, akuntansi, perbendaharaan,dan pengawasan internal serta pemeriksaan intern. Total responden yang menerima kuesioner adalah berjumlah 55 orang, dimana kuesioner yang kembali hanya 51 kuesioner, karena 4 orang tidak kembali karena alasan tertentu. Adapun Analisis yang digunakan dalam penelitian ini adalah analisis regresi linear berganda, dimana model penelitian adalah sebagai berikut.

$\mathrm{Y} \quad=$ variabel terikat Kinerja Pemerintah Daerah

$$
\mathbf{Y}=\alpha+\beta_{1} \mathbf{X}_{1}+\beta_{2} \mathbf{X}_{2}+\beta_{3} \mathbf{X}_{3}+\mathbf{e}
$$

$\alpha \quad=$ konstanta

$\beta_{1} \quad=$ koefisien regresi $X_{1}$

$\beta_{2} \quad=$ koefisien regresi $\mathrm{X}_{2}$

$\beta_{3} \quad=$ koefisien regresi $X_{3}$

$\mathrm{X}_{1} \quad=$ variabel bebas Implementasi Sistem Akuntansi

$\mathrm{X}_{2} \quad=$ variabel bebas Pengelolaan Keuangan Daerah

$\mathrm{X}_{3} \quad=$ variabel bebas Pengawasan Internal

$\mathrm{e} \quad=$ error

Adapun definisi operasional dan pengukuran variabel dalam penelitian ini adalah sebagai berikut :

a. Implementasi Sistem Akuntansi, yang merupakan penjabaran pedoman pokok penyusunan dan penyajian laporan keuangan pemerintah. Variabel ini diukur dengan menggunakan skala Likert 1-5.

b. Pengelolaan Keuangan Daerah, yang merupakan suatu aktivitas mencakup tahap perencanaan, tahap penyusunan dan penetapan APBD, tahap pelaksanaan APBD termasuk bagaimana kegiatan penatausahaannya, serta tahap pertanggungjawaban dan pengawasan. Variabel ini diukur dengan menggunakan skala Likert 1-5.

c. Pengawasan Intern, yang merupakan fungsi penilaian independen dalam suatu organisasi untuk menguji dan mengevaluasi kegiatan organisasi yang dilakukan. Variabel ini diukur dengan menggunakan skala Likert 1-5.

d. Kinerja Pemerintah Daerah, yang merupakan gambaran mengenai tingkat pencapaian pelaksanaan suatu kegiatan/program/kebijaksanaan dalam mewujudkan sasaran, tujuan, misi dan visi organisasi yang tertuang dalam perumusan skema strategis suatu organisasi. Secara umum dapat dikatakan juga bahwa kinerja merupakan prestasi yang dapat dicapai organisasi dalam periode tertentu. Variabel ini diukur dengan skala Likert 1-5.

\section{HASIL ANALISIS DAN PEMBAHASAN}

\subsection{Hasil Analisis}

Hasil analisis dengan menggunakan uji t menunjukkan bahwa : (1) Sistem Akuntansi $\left(\mathrm{X}_{1}\right)$ berpengaruh signifikan dan searah/positif terhadap Kinerja Pemerintah Daerah pada Pemerintah Kota Kotamobagu; (2) Pengelolaan Keuangan Daerah $\left(\mathrm{X}_{2}\right)$ berpengaruh signifikan dan searah/positif terhadap Kinerja Pemerintah Daerah pada Pemerintah Kota 
Kotamobagu; dan (3) Pengawasan Internal $\left(\mathrm{X}_{3}\right)$ tidak berpengaruh signifikan dan searah/positif terhadap Kinerja Pemerintah Daerah pada Pemerintah Kota Kotamobagu.

\subsection{Pembahasan}

\subsubsection{Hubungan Sistem Akuntansi berpengaruh dan Kinerja Pemerintah Daerah pada Pemerintah Kota Kotamobagu.}

Sistem Akuntansi sangat diperlukan untuk menjamin konsistensi dalam pelaporan keuangan dan dapat dijadikan pedoman dalam menyajikan informasi yang diperlukan berbagai pihak. Tidak adanya sistem akuntansi yang memadai akan menimbulkan implikasi negatif berupa rendahnya reliabilitas dan objektivitas informasi yang disajikan dan inkonsistensi dalam pelaporan keuangan. Sangat penting dalam suatu pemerintahan mempunyai sistem informasi akuntansi yang mengedepankan orang-orang, prosedur, data, software dan infrastruktur teknologi informasi yang nantinya akan menghasilkan informasi akuntansi berupa laporan keuangan yang sangat diperlukan dalam dunia pemerintahan. Salah satu kriteria sistem informasi akuntansi yang baik adalah menghasilkan informasi yang berkualitas. Sistem Akuntansi di Pemerintahan Kota Kotamobagu sudah menerapkan PP.71 tahun 2010 sehingga terjadi keefektifan pelaporan keuangan di daerah tersebut dan membuat kinerja dari pemerintah Kota Kotamobagu menjadi baik.

\subsubsection{Hubungan Pengelolaan Keuangan Daerah dan Kinerja Pemerintah Daerah pada Pemerintah Kota Kotamobagu.}

Pengelolaan keuangan dilaksanakan berdasarkan penatausahaan keuangan. Namun pelaksanaan sistem belum menjamin tidak terjadinya kesalahan/penyimpangan, sehingga diperlukan metode pengawasan intern yang memadai dan dapat memberikan bantuan untuk memverifikasi transaksi-transaksi agar dapat telusuri dana-dana sesuai dengan tujuannya serta mengecek otoritas, efisiensi dan keabsahan pembelajaran dana. Pengelolaan keuangan daerah di Kota Kotamobagu berorientasi pada kinerja sasaran strategis dan alokasi dana. Tahap perencanaan, penatausahaan dan pertanggungjawaban tercipta dengan baik sehingga kinerja yang diharapkan menjadi naik pula. Proses pengelolaan keuangan terkait antara yang dianggarkan dan yang ingin dicapai. Sumber daya yang ada memiliki kualitas dan mutu yang baik sehingga menunjang keberhasilan kinerja pemerintah daerah.

\subsubsection{Hubungan Pengawasan Internal dan Kinerja Pemerintah Daerah pada Pemerintah Kota Kotamobagu.}

Pengawasan intern adalah sebagai usaha sistematis untuk menetapkan standar kegiatan dengan tujuan perencanaan, menyusun sistem informasi umpan balik, membandingkan kegiatan yang dilakukan dengan standar, menentukan, serta mengukur pertimpangan dan melakukan tindakan yang diperlukan untuk menjamin bahwa semua sumber dipergunakan secara efektif dan efisien untuk mencapai tujuan organisasi. Pengawasan dilakukan pada semua tingkatan manajemen. Para pemimpin tingkat atas pengawasan dilakukan pada seluruh bagian atau unit pemerintah. Sedang pada tingkat menengah dan bawah, pengawasan dilakukan pada unit pimpinannya masing-masing. Pengawasan internal berpengaruh tapi tidak signifikan karena fungsi ini perlu ditingkatkan lagi mulai dari analisis, dan saran-saran perbaikan atas penyimpangan yang ditemukan. Pengawasan internal harus lebih memonitor semua program dan kegiatan operasional Pemerintah Kota Kotamobagu pada semua tingkatan. Pengawasan internal dituntut untuk lebih giat lagi melakukan koreksi atas penyimpangan dari kinerja yang diinginkan.

\section{KESIMPULAN DAN SARAN}

Berdasarkan hasil analisis dan pembahasan, maka penelitian ini menyimpulkan bahwa, Implementasi Sistem Akuntansi berpengaruh signifikan dan searah/positif terhadap Kinerja Pemerintah Daerah pada Pemerintah Kota Kotamobagu. Sistem Akuntansi di Pemerintahan Kota Kotamobagu sudah menerapkan PP No. 71 tahun 2010 sehingga terjadi 
keefektifan pelaporan keuangan di daerah tersebut dan membuat kinerja dari pemerintah Kota Kotamobagu menjadi baik. Selain itu, Pengelolaan Keuangan Daerah berpengaruh signifikan dan searah/positif terhadap Kinerja Pemerintah Daerah pada Pemerintah Kota Kotamobagu. Pengelolaan Keuangan Daerah di Kota Kotamobagu berorientasi pada kinerja yaitu sasaran strategis dan alokasi dana. Semua tahap mulai dari perencanaan, penatausahaan dan pertanggungjawaban tercipta dengan baik sehingga kinerja yang diharapkan menjadi naik pula. Sedangkan, Pengawasan Internal tidak berpengaruh signifikan dan searah/positif terhadap Kinerja Pemerintah Daerah pada Pemerintah Kota Kotamobagu. Pengawasan internal harus lebih memonitor semua program dan kegiatan operasional Pemerintah Kota Kotamobagu pada semua tingkatan. Pengawasan internal dituntut untuk lebih giat lagi melakukan koreksi atas penyimpangan dari kinerja yang diinginkan.

Penelitian ini menyarankan agar Pemerintah Kota Kotamobagu lebih meningkatkan lagi sistem reward and punishment, sehingga dapat meningkatkan motivasi para aparat pemerintah Kota Kotamobagu untuk melaksanakan tugasnya dengan lebih baik lagi. Selain itu, dengan semakin meningkatnya kinerja pemerintahan Kota Kotamobagu, maka hal ini harus dipertahankan atau juga dapat ditingkatkan lagi pada pengawasan internal. Pengawasan internal harus lebih menjadi konsultan intern, dan banyak memberikan saran perbaikan dan koreksi yang benar dalam rangka pengingkatan kinerja yang lebih baik lagi, sehingga lebih siap lagi apabila diperhadapkan dengan perubahan-perubahan kebijakan di lingkungan pemerintahan pada masa mendatang.

\section{DAFTAR PUSTAKA}

Baridwan, Zaki. 2004.Intermediate Accounting. Edisike 7. BPFE. Yogyakarta. Baswir, R. 1999. Akuntansi Pemerintahan Indonesia. BPFE. Yogyakarta.

Fawzi, Anggi. 2012. Pengaruh Pengawasan Intern dan Sistem Informasi Akuntansi terhadap Kinerja Pemerintahan(Survei pada Organisasi Perangkat Daerah (OPD) Pemerintah Kota Tasikmalaya). Jurnal. Universitas Siliwangi. Siliwangi.

Fess., Warren., Reeve. 2002. Accounting. 20 ${ }^{\text {th }}$ Edition. South Western a Division of Thomson. USA.

Govermental Accounting Standard Board.1994. Concepts Statements No. 2, Service Efforts and Accomplishment Reporting. www.rutgers.edu/Accounting/raw/seagov/pmg/perfmeasure, diakses September 2000.

Halim, Abdul. 2007. AkuntansiSektorPublik : Pengelolaan Keuangan Daerah. Edisi ketiga.Salemba Empat. Jakarta.

Halim, A., dan Rohman. 2008. Pengaruh Peran Manajerial Pengelola Keuangan Daerah dan Fungsi Pengendalian Intern terhadap Kinerja Pemerintah Daerah. Jurnal Maksi Vol7 No.2. Universitas Diponegoro. Semarang.

Halim, A., dan Rohman. 2009.Pengaruh Implementasi Sistem Akuntansi, Pengelolaan Keuangan Daerah Terhadap Fungsi Pengawasan Dan Kinerja Pemerintah Daerah (Survei PadaPemda Di Jawa Tengah).Jurnal Akuntansi \& Bisnis Vol.9 No.1 ISSN 1412-0852.Universitas Diponegoro. Semarang.

Hongren., Harrison., Bamber. 2002.Accounting. $5^{\text {th }}$ Edition. Prentice Hall Inc. New Jersey. Ihyaul, Ulum. 2004. Akuntasi Sektor Publik: Suatu Pengantar. Bumi Aksara. Jakarta.

Jogiyanto, H.M. 2003 Sistem Teknologi Informasi Pendekatan Terintegrasi :Konsep Dasar, Teknologi, Aplikasi, Pengembangan dan Pengelolaan. Edisi Pertama. Andi. Yogyakarta.

Jusuf, Al-Haryono. 2001.Dasar-DasarAkuntansi. Edisi Enam. STIE Yayasan Keluarga Pahlawan Negara.Yogyakarta. 
LAN dan BPKP. 2000. Akuntabilitas dan Good Governance. LAN. Jakarta.

Mardiasmo.2002.2004.Akuntansi Sektor Publik. Andi Offset. Yogyakarta.

Mulyadi.2001.SistemAkuntansi. Edisi Ketiga. Cetakan Ketiga.Salemba Empat.Jakarta.

Parker, Wayne C. 1993.Performance Measurement in the Public Sector.State ofUtah. www.rutgers.edu/Accounting/raw/seagov/pmg/perfmeasure, diakses September2000.

Republik Indonesia.Permendagri No. 59 Tahun 2007 tentang Pedoman Pengelolaan Keuangan Daerah. Jakarta.

Republik Indonesia. Peraturan Pemerintah No.58 tahun 2005 tentang pengelolaan dan pertanggungjawaban keuangan daerah. Jakarta.

Sadeli, Lili M., Siswanto, Bedjo. 2004. Akuntansi Manajemen. PT. Bumi Aksara. Jakarta.

Sarjono, Haryadi.,Julianita Winda. 2011. SPSS vs LISREL. Salemba Empat. Jakarta.

Sarwono, Jonathan. 2012. Path Analysis. Elex Media Komputindo. Jakarta.

Simamora, Henry.2000. Akuntansi Basis Pengambilan Keputusan Bisnis. Jilid Pertama. Salemba Empat.Jakarta.

Sukmana.,Wawan., Anggasari.,Lia. 2009. Pengaruh Pengawasan Intern Dan Pelaksanaan Sistem Akuntansi Keuangan Daerah Terhadap Kinerja Pemerintah Daerah

( Survei Pada Satuan Kerja Perangkat Daerah Kota Tasikmalaya ). Jurnal Akuntansi FE Unsil, Vol. 4, No. 1, 2009.ISSN : 1907 - 9958. Fakultas Ekonomi Universitas Siliwangi. 